\title{
Understanding the Impacts of Chinese Undergraduate Tourism Students' Professional Identity on Learning Engagement
}

\author{
Fenglong Yu*, Qian Chen and Bing Hou
}

check for updates

Citation: Yu, F.; Chen, Q.; Hou, B. Understanding the Impacts of Chinese Undergraduate Tourism Students' Professional Identity on Learning Engagement. Sustainability 2021, 13, 13379. https://doi.org/ $10.3390 /$ su132313379

Academic Editor: Jordi Colomer Feliu

Received: 13 October 2021

Accepted: 30 November 2021

Published: 3 December 2021

Publisher's Note: MDPI stays neutral with regard to jurisdictional claims in published maps and institutional affiliations.

Copyright: (c) 2021 by the authors. Licensee MDPI, Basel, Switzerland. This article is an open access article distributed under the terms and conditions of the Creative Commons Attribution (CC BY) license (https:/ / creativecommons.org/licenses/by/ $4.0 /)$.
School of Tourism and Cuisine, Yangzhou University, Yangzhou 225127, China; qian.chen@yzu.edu.cn (Q.C.); bhou@yzu.edu.cn (B.H.)

* Correspondence: 006541@yzu.edu.cn

\begin{abstract}
Under the background of higher education reform, undergraduate tourism students' professional identity may play an important role in affecting students' learning engagement and the sustainable development of tourism higher education. Data were collected from 551 Chinese undergraduate tourism students to investigate the potential relationships between professional identity and learning engagement. Based on the theory of social identity, professional identity is perceived as a progressive, dynamic process including professional cognition, professional appraisal, and professional emotion. The data were analyzed using structural equation modeling (SEM), and the findings confirmed that professional identity was in positive correlation with employee engagement. Furthermore, the results showed that professional cognition has positive influences on professional appraisal, professional emotion, and learning engagement, and professional appraisal has positive influences on professional emotion and learning engagement. In addition, the mediating effects of professional appraisal and professional emotion between professional cognition and learning engagement were analyzed, respectively. This study contributes to the understanding of the impacts of tourism students' professional identity on learning engagement. Both theoretical and practical implications are provided.
\end{abstract}

Keywords: professional identity; learning engagement; undergraduate; tourism higher education; China

\section{Introduction}

In accordance with the development of the tourism industry all over the world, the number of tourism higher education institutions, teachers, and students is increasing rapidly [1]. Similarly, the prosperity of the Chinese tourism industry has accelerated the development of tourism education since the reform and opening-up policy in 1978, and the number of tourism universities in China has ranked among the top in the world. However, problems are also detected that tourism degrees of some key universities have shrunk, students' professional identity has been declining, and the turnover rate of tourism employees is high $[2,3]$. The structural imbalance between tourism talent supply and tourism industrial demand has seriously weakened the quality of talent training and the sustainable development of the tourism industry [4,5]. In particular, the relatively low professional identity of tourism university students is one of the important reasons [6,7].

The COVID-19 pandemic has highlighted the vulnerability of the tourism industry [8]. The quality of tourism higher education is questioned because of lower quality student intake and poorer academic performance [9]. The COVID-19 pandemic has severely impacted employment in the tourism and hotel industry, with an estimated 100-120 million direct job losses worldwide at the beginning of the epidemic [10]. Since the outbreak of COVID-19, tourism education was also badly affected, and re-building students' professional confidence has attracted extensive attention [11-13]. The number of Chinese students who would like to choose tourism majors for university education has been declining, and 
the rate of transferring tourism majors has increased after entering university [14]. Accordingly, the employment rate of the tourism-related industry has decreased [15]. With the additional competition among different majors in Chinese higher education, the tourism major in Chinese universities is facing a survival crisis [16]. Therefore, it is significant to strengthen and improve Chinese undergraduate tourism students' professional identity and enhance their learning engagement and employment competitiveness.

Professional identity has been an important aspect of higher education development. It is an important measure of learners' own values, as well as career development goals [17]. It has been shown that professional identity plays an important role in the breakthrough and upgrading of the tourism discipline. However, undergraduate tourism students' professional identity has not been well investigated. As a focus of higher education research, learning engagement is perceived as an important predictor of academic success [18] Learning engagement is usually used to describe the phenomenon and state of students' active involvement in learning tasks, and refers to the positive and fulfilling mental state related to learning [19], and seems to be a generally accepted and unchallenged orthodox academic belief [20]. Relevant research shows the more students involved in learning, the better they gain from learning in all aspects [21].

Some studies have confirmed that there is a significant correlation between university students' professional identity and learning engagement. However, how professional identity affects learning engagement needs to be further studied [22,23]. The relationship between professional identity and learning engagement is not a simple linear correlation and may be regulated by students' personality, teaching environment and level, and so on [24-27]. In addition, Chinese students' professional identity and learning engagement have received little research attention [28]. Does the professional identity of Chinese undergraduate tourism students affect learning engagement? How does it affect learning engagement?

This study is helpful in contributing to the development of professional identity theory through investigating Chinese undergraduate tourism students' professional identity and learning engagement. In particular, the contributions of the study are revealed as follows. Firstly, this study contributes to the development of the scale of professional identity. Secondly, this study evaluates the professional identity status of Chinese undergraduate tourism students. Thirdly, this study investigates the relationships between professional identity and learning engagement.

In order to achieve the above purpose, the following hypotheses are proposed: Does undergraduate tourism students' professional identity have a positive impact on learning engagement? Can students' professional identity be understood from three aspects: cognition, appraisal, and emotion? What are the relationships among professional cognition, professional appraisal, professional emotion and learning engagement? The structure of the paper is presented as follows. First, based on the social identity theory, this study explores the connotation of professional identity and proposes the research hypotheses and model. Second, the methodology is introduced to examine and validate the scale of professional identity. Third, this study applies the structural equation model to test the relationship between professional identity (including three dimensions: professional cognition, professional appraisal, and professional emotion) and learning engagement. Finally, conclusions and implications are discussed based on the results. The study's limitations and future research directions are also presented.

\section{Literature Review and Hypothesis Development}

\subsection{Social Identity Theory}

The concept of social identity was derived from group identity, referring to an individual's belief or that he/she was a member of the group [29]. The theory of social identity focuses on the sense of identity that individuals belong to the social category or group and the impacts of this sense on individual behaviors [30]. The theory holds that group members demarcate group boundaries according to strategies such as social classification, 
social comparison, or positive differentiation and take different behaviors [31]. Based on the similarities and differences within and outside the group, individuals identify with or distinguish themselves from a group, and identify with an in-group or discriminate against an out-group cognitively, emotionally, and behaviorally [32,33].

Therefore, the theory of social identity was helpful to understand university students' professional identity from three aspects: cognition, appraisal, and emotion [34]. Specifically, the cognitive component refers to the process of students' understanding of the major by learning professional knowledge, an evaluative component refers to the positive or negative evaluation of the fit between individuals and groups, and the emotional component refers to the individual's attachment to the group and other members [30]. Social identity theory attaches importance to stimulating individual social emotion through self-cognition, evaluation, and classification, which is not only a dynamic action process but also a relatively stable action result $[32,33]$. For example, Dick et al. developed the organizational identity scale that consists of four dimensions: cognition, emotion, evaluation, and behavior [35]. This theory provides a theoretical basis to understand professional identity and to examine the relationship between professional identity and learning engagement.

\subsection{Professional Identity (PI)}

The professional identity is usually understood as the internalization of values, identification of the major or occupation, and psychology unification [36]. At present, the research of professional identity focuses on the areas including the dimensions and measurement of professional identity, the relationship between professional identity, job satisfaction, turnover rate, and so on [37-39]. In particular, many studies discussed the formation of professional identity in the social context, and professional identity was characterized with a multi-dimensional structure, referring to a continuous, constantly changing active process [40]. In contrast, there was less research in the Chinese context, especially undergraduate tourism students' professional identity. The limited research focuses on the discussion of the connotation and dimensions of professional identity and the influential factors of professional identity $[18,24,41]$.

Based on the above analysis and the theory of social identity, university students' professional identity was gradually constructed as a dynamic psychological process from professional cognition, professional appraisal to professional emotion [42,43]. Specifically, undergraduate tourism students acquire professional knowledge of tourism theory and industry and a construct of the professional cognition of the tourism major [44]. Based on the cognition of the tourism major, university students evaluated the matching degree between themselves and the majors and generated positive or negative evaluations [45]. Consequently, it will lead to students' emotional acceptance and attachment to the tourism major, which in turn promotes their learning engagement. Adversely, it might also produce the opposite result $[46,47]$. The above understanding of professional identity can be summarized as a dynamic, progressive process consisting of three dimensions: professional cognition, professional appraisal, and professional emotion [45]. The first dimension influences the second dimension; different dimensions may not only have a direct influence on learning engagement but also have indirect influence through other variables $[26,27]$.

An individual's cognitive state and psychological process have significant impacts on professional appraisal and professional emotion [48,49]. According to Control-value theory $(\mathrm{CVT})$, cognitive appraisals and emotions govern motivation and learning in achievement settings [42]. High levels of perceived control and value indicate higher levels of positive emotions and lower levels of negative emotions [50]. University students can experience different cognitions, appraisals, and emotions in learning settings. Cognitive appraisal theory (CAT) also shows that the beliefs guide the emotional response [51]. Cognition appraisal can affect students' emotional state, and the appraisal is a significant factor in developing emotions in the study process [52,53]. Consequently, the following hypotheses are proposed: 
Hypotheses 1 (H1). University students' professional cognition is positively related to professional appraisal.

Hypotheses 2 (H2). University students' professional cognition is positively related to professional emotion.

Hypotheses 3 (H3). University students' professional appraisal is positively related to professional emotion.

Hypotheses 4 (H4). Professional appraisal mediates the effects of professional cognition on professional emotion.

\subsection{Learning Engagement (LE)}

Learning is a complex human activity. Examining the process and conditions of learning has always been one of the most interesting topics for scholars [54,55]. Since the 21st century, university students' learning engagement has become one of the focuses to improve higher education quality [56]. At present, in the field of higher education, the research on learning engagement mainly focus on the following aspects: constructing theoretical concept, measuring learning engagement, carrying out empirical research, exploring influencing process, and examining the effects of learning engagement $[54,57,58]$. Learning engagement is closely related to their academic achievement, ability development and learning satisfaction [59], and conduciveness to stimulate students' positive qualities such as optimism, resilience, creativity, and job satisfaction, which effectively promote the maturity and development of students and lay a solid foundation for them to enter society $[38,60]$.

Learning engagement could be understood as the individual psychological state of learners in learning activities, which was a composite concept containing multiple dimensions such as behavior, emotion, and cognition [61,62]. Learning engagement was a lasting and perfect cognitive and emotional state related to learning, scientific research, and employment, which was an important indicator of students' positive learning psychology [63]. Many studies have proven the relationships between cognitions appraisal, emotions, and learning performance [50,54,61]. Skinner et al. proposed the self-system model of motivational development (SSMMD) [61]. The positive emotions could improve university students' satisfaction and creative learning, and negative emotions will lead to negative behaviors. The model has been widely used in the field of higher education research, which confirms the influence of environmental perception and emotion on learning engagement $[18,19,64]$. Vermunt and Vermetten put forward the concept of learning pattern, which includes cognition, emotion, and regulation [65]. Biggs et al. proposed a classic three-stage model of "presage-process-product" to explain the learning process of university students [66]. Song and Qu examined the mediating role of consumption emotions [67]. The above models show the interaction between the individual characteristics of students and the learning environment from different levels, forming students' perception and experience of the learning environment and then influencing the learning style, and the learning results.

There were a few studies on undergraduate tourism students' engagement $[24,68,69]$. Some scholars have introduced and revised the learning engagement scale by Schaufeli et al. [22], tested its reliability and validity in the context of Chinese culture, and have shown good results [68]. Based on the previous investigation and communication with tourism teachers and students in many Chinese universities, it was found that university students' low learning engagement and weak learning enthusiasm has become a common problem among undergraduate tourism students [6,7]. This might be due to many factors, such as social and cultural background, tourism industry development and employment prospects, and professional courses, and so on [2]. These factors also have a certain relationship with professional identity and learning engagement. Therefore, the hypotheses are formulated as follows: 
Hypotheses 5 (H5). University students' professional cognition is positively related to learning engagement.

Hypotheses 6 (H6). University students' professional appraisal is positively related to learning engagement.

Hypotheses 7 (H7). University students' professional emotion is positively related to learning engagement.

Hypotheses 8 (H8). Professional emotion mediates the effects of professional appraisal on learning engagement.

Hypotheses 9 (H9). Professional appraisal mediates the effects of professional cognition on learning engagement.

Hypotheses 10 (H10). Professional emotion mediates the effects of professional cognition on learning engagement.2.4. Relationship between professional identity (PI) and learning engagement (LE).

In recent years, many scholars have carried out the study of professional identity and learning engagement. Most studies showed that there was a significant positive correlation between professional identity and learning engagement [23-25,28]. Students with a high professional identity can prevent the continuous decrease of learning enthusiasm, which results in the increase of learning engagement. For example, Tang examined the influences of professional identity on job satisfaction of rural teachers in mainland China [24]. It is noted that professional identity was influential in work engagement, was helpful in improving job satisfaction, and reducing turnover intention.

Figure 1 demonstrates the theoretical model of the hypothesized relationships among professional identity (professional cognition, professional appraisal, and professional emotion) and learning engagement.

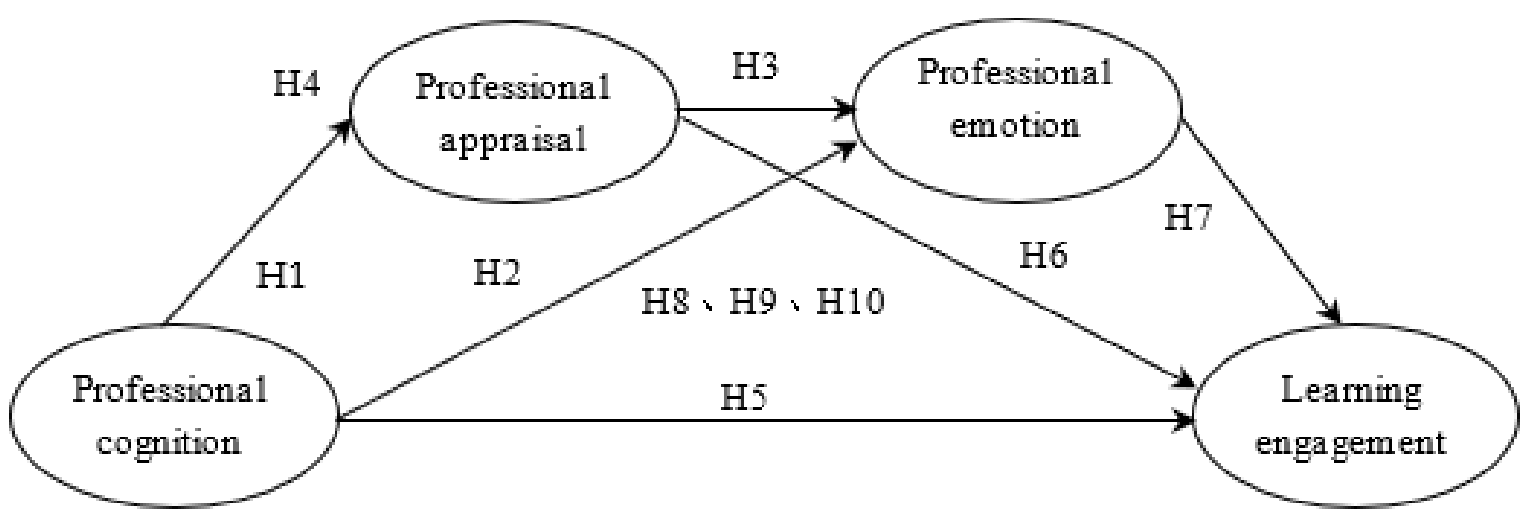

Figure 1. A theoretical model of impacts of tourism students' professional identity on learning engagement.

\section{Methodology}

\subsection{Research Instrument}

Based on the existing research, a questionnaire was developed to measure tourism students' professional identity and learning engagement. In particular, the scale to measure students' professional identity was adapted from a number of studies $[35,45,70]$. The scale included three aspects in the context of Chinese tourism higher education: professional cognition, professional appraisal, and professional emotion. Next, in terms of measuring learning engagement, a scale was adapted from the Utrecht Work Engagement ScaleStudent (UWES-S) [22]. Many studies have proved the reliability and validity of the UWES-S scale for Chinese university students [71,72].

The questionnaire consists of three parts: the first section examines Chinese undergraduate tourism students' professional identity, the second section investigates students' learning engagement, and the third section examines the demographic profiles of respon- 
dents, such as gender, grade, family source, and admission type of university entrance examination. These items were rated utilizing a five-point Likert scale from 1 (completely disagree) to 5 (strongly agree).

\subsection{Data Collection}

Data for this study was collected through the questionnaire survey with undergraduate tourism students from 10 large public universities located in Jiangsu province, China. Jiangsu province was located in the coastal area of eastern China. The number of universities and the development level of the tourism industry in Jiangsu province is in the forefront of the country. At present, about 30 universities in Jiangsu province have set up tourism degrees at undergraduate level, and there are 9000-10,000 undergraduate tourism students. In addition, there are many types of undergraduate levels, for example, national key universities, provincial key universities, and local general universities. Researchers have been engaging in tourism education and tourism research in Jiangsu, and are also familiar with the development process and existing problems of tourism education in Jiangsu. Therefore, taking Jiangsu province as the research area was representative to investigate university undergraduate tourism students' professional identity. The theoretical and empirical implications of the study would be more meaningful and more enlightening for other relatively less developed provinces.

The research team maintained good communication and contact with universities in Jiangsu province, which is conducive to data collection and effectiveness. According to the geographical and professional characteristics, ten representative universities were contacted and agreed to participate in the data collection.

The data collection took approximately two months, from May to June 2021. Firstly, a small-scale pre-survey was carried out to evaluate the initial questionnaire, purify and revise the items, and finalize the questionnaire for a formal investigation. Specifically, a total of 300 questionnaires were distributed to three universities in Jiangsu, and 251 valid questionnaires were retained after screening. The response rate of valid questionnaires was $83.6 \%$. Second, a stratified random sample method was applied. According to the number of undergraduate tourism students, and the level of the university, ten representative universities were contacted and agreed to participate in the data collection. Then, a simple random sampling method was adopted to extract the above number of sample units from the ten universities. We tried to reduce the sampling error. A large-scale formal survey was carried out, and 700 questionnaires were distributed to 10 universities in Jiangsu. A total of 149 questionnaires were eliminated owing to unengaged responses, and 551 valid questionnaires were retained, resulting in a valid response rate of $78.7 \%$.

\subsection{Data Analysis}

Data analysis included the following steps. First, a descriptive analysis was conducted through the SPSS version 18 statistical package to detect the normality and multicollinearity problems. Second, exploratory factor analysis (EFA) was performed on the initial sample (251 cases) to measure the reliability and validity of the questionnaire. Third, confirmatory factor analysis (CFA) was performed on the formal survey (551 cases) of the measurement model. Finally, a structural equation model (SEM) using SPSS AMOS24.0 package was conducted to test the proposed conceptual model.

\subsection{Ethical Consideration}

The researchers followed the standard requirements of research. The purposes of the research were explained before asking the students to volunteer for the survey to ensure the participation was voluntary and respondents' personal information was kept unidentifiable in the research process. The research was approved by the researchers' university Ethics Committee on 5 May 2021. 


\section{Results}

\subsection{Demographic Characteristics of Respondents}

Table 1 describes the demographic characteristics of the respondents. Among the 551 respondents in the study, $77.9 \%$ were female and $22.1 \%$ were male, showing consistency with the fact that there were more female students than male students in tourism major in China [73]. In terms of grade distribution, freshmen and junior students accounted for 29.8 and $31.0 \%$, respectively, while sophomore and senior students accounted for 20.1 and $19.1 \%$, respectively. Concerning the family sources, university students from urban and rural areas accounted for 35.8 and $38.1 \%$, respectively, and $26.1 \%$ of university students come from small towns. In terms of university admission, students who take tourism major as their first choice accounted for $25.3 \%$, and the students who take tourism major as their second and third choices reached $25.0 \%$. However, the proportion of adjusted admission reached $32.5 \%$. Adjusted admission means that the examinee is not accepted by their chosen universities in the admission, and the examinee is subject to the adjustment of the admissions department and is admitted by other universities that have not completed the enrollment plan.

Table 1. Demographic profile of respondents $(\mathrm{N}=551)$.

\begin{tabular}{ccc}
\hline Demographic Category & Sample Size & Frequency (\%) \\
\hline Gender & 122 & 22.1 \\
Male & 429 & 77.9 \\
Female & & \\
Family source & 197 & 35.8 \\
Urban area & 144 & 26.1 \\
Small town & 210 & 38.1 \\
Rural area & & \\
Grade & 164 & 29.8 \\
Freshman & 111 & 20.1 \\
Sophomore & 171 & 31.0 \\
Junior & 105 & 19.1 \\
Senior & & \\
university Admission & 137 & 24.9 \\
First choice & 65 & 11.8 \\
Second choice & 80 & 14.5 \\
Third choice & 96 & 17.4 \\
Other choice & 173 & 31.4 \\
Adjusted admission & &
\end{tabular}

\subsection{Exploratory Factor Analysis (EFA)}

In order to explore the factor structure of Chinese university students' professional identity, exploratory factor analysis (EFA) was conducted with the initial sample $(\mathrm{N}=251)$. Given the Kaiser-Meyer-Olkin (KMO) measure of sampling adequacy (0.929) and Bartlett's test of sphericity $\left(\chi^{2}=3237.119, p<0.001\right)$, which confirmed the appropriateness of the factor structure. Specifically, the criteria that eigenvalues greater than one, the identified factors, and indicators could be interpretability in theory and stability is used to determine the number of factors [74]. A total of three items were deleted due to their failure to meet the threshold of 0.5 [75].

The results of EFA are presented in Table 2. The extracted 14 measurement items accounted for $74.33 \%$ of the total variance. Specifically, professional cognition had four items $(8.509 \%)$, the professional appraisal had four items $(12.587 \%)$, and professional emotion had six items (53.234\%). This study used Cronbach's alpha as an indicator of internal consistency; the results demonstrated that the score of the structure size was 0.923 (professional emotion), 0.903 (professional appraisal), and 0.864 (professional cognition), exceeding the recommended threshold of 0.70 . The above results showed that the construct of professional identity consisted of three dimensions: professional cognition, professional 
appraisal, and professional emotion. Specifically, the dimension of professional cognition refers to an individuals' understanding of the history, current situation, and future development of tourism major, reflecting their identity consciousness of belonging to a certain group. The dimension of professional appraisal refers to an individual's evaluation of the degree of conformity between his personality, personal development, and tourism major. The dimension of professional emotion refers to an individual's attachment to the tourism major, which is manifested in professional confidence, employment intention, emotional belonging, and satisfaction degree.

Table 2. Exploratory factor analysis of constructs.

\begin{tabular}{|c|c|c|c|}
\hline Items & $\begin{array}{c}\text { Factor } \\
\text { Loadings }\end{array}$ & $\begin{array}{l}\text { Cronbach's } \\
\text { Alpha }\end{array}$ & Mean \\
\hline Professional cognition (PC) & & 0.923 & 3.48 \\
\hline PC: 1 I know the employment situation of tourism major & 0.784 & & \\
\hline PC 2: I know the position of tourism major in our university & 0.812 & & \\
\hline PC 3: I know the external evaluation of tourism major & 0.854 & & \\
\hline PC 4: On the whole, I have a clear understanding of tourism major & 0.736 & & \\
\hline Professional appraisal (PA) & & 0.903 & 3.30 \\
\hline PA 1: I have a good tourism professional thinking & 0.749 & & 3.34 \\
\hline PA 2: My character matches tourism major & 0.837 & & 3.25 \\
\hline PA 3: Tourism major can reflect my character & 0.831 & & 3.16 \\
\hline PA 4: I feel very relaxed studying tourism & 0.803 & & 3.45 \\
\hline Professional emotion (PE) & & 0.864 & 3.71 \\
\hline PE 1: I am willing to engage in work related to tourism & 0.730 & & 3.30 \\
\hline PE 2; I have accepted the tourism major in my heart & 0.697 & & 3.46 \\
\hline PE 3: I have a positive evaluation of tourism major & 0.810 & & 3.70 \\
\hline PE 4: I have great confidence in the development prospect of a tourism major & 0.823 & & 3.68 \\
\hline PE 5: I have a positive feeling for tourism major & 0.769 & & 3.40 \\
\hline PE 6: I am basically satisfied with the tourism major of our university & 0.735 & & 3.32 \\
\hline
\end{tabular}

\subsection{Confirmatory Factor Analysis (CFA)}

Confirmatory factor analysis (CFA) was conducted with the second sample $(\mathrm{N}=551)$ to verify whether the factor structure of the questionnaire scale was well adapted to the sample data. Multiple measures were used to assess the model fit, including $\chi^{2} / \mathrm{df}, \mathrm{GFI}$, RMSEA, RMR, CFI, NFI, IFI [76]. The fit indices were as follows: $\chi^{2} / \mathrm{df}=3.27, \mathrm{GFI}=0.94$, $\mathrm{CFI}=0.96, \mathrm{NFI}=0.94, \mathrm{IFI}=0.96, \mathrm{RMSEA}=0.06$, and RMR $=0.04$. The estimation of the model provided an acceptable fitting [77]. After proper modification of the model, the final measurement model was obtained. The values of standardized loading ranged from 0.556 to 0.882 , and $t$-values were between 11.678 and 18.107 , and the loadings of all factors were statistically significant. CFA confirmed the findings of EFA, and each indicator of professional identity was highly fitted to the expected dimension.

For the data analysis, the model was verified when the average variance extracted (AVE), Cronbach's alpha and CR confirmed the discriminant validity [76]. The CR (composite reliability) of the constructs was obtained from the CFA results. The CR was used to test the internal consistency for the constructs, and the $C R$ values exceeded the recommended threshold $(C R>0.70)$. As Tables 2 and 3 show, the $C R$ values of the construct ranged from 0.784 to 0.93 , exceeded 0.70 .

Apart from the AVE value of the professional cognition was 0.48 , slightly lower than 0.5 , the AVE values of other variables ranged from 0.584 to 0.816 . The discriminant validity of latent variables was tested by checking whether the square root AVE of each variable was superior to the correlation [78]. Table 3 shows the research results of CFA, CR, AVE, mean, and the correlations of the constructs. Therefore, validity and reliability were established for the proposed model. 
Table 3. Correlations and squared correlations of constructs.

\begin{tabular}{cccccccc}
\hline Construct & \multirow{2}{*}{ CR } & AVE & Mean & \multicolumn{4}{c}{ Discriminant Validity (Correlations and Square Root of AVE) } \\
\cline { 6 - 8 } & & & & PE & PM & PC & LE \\
\hline Professional emotion (PE) & 0.858 & 0.607 & 3.48 & 0.779 & & & \\
Professional appraisal (PA) & 0.893 & 0.584 & 3.30 & 0.669 & 0.764 & 0.695 & 0.375 \\
Professional cognition (PC) & 0.784 & 0.483 & 3.71 & 0.508 & 0.406 & 0.903 \\
Learning engagement (LE) & 0.930 & 0.816 & 3.30 & 0.458 & 0.504 & 0.375 \\
\hline
\end{tabular}

Table 2 shows that the mean value of each factor of professional identity ranged from 3.16 to 3.85, Table 3 shows that the mean value of professional emotion, professional appraisal, professional cognition, and learning engagement ranged from 3.30 to 3.71 . This result illustrated that the degree of Chinese undergraduate tourism students' professional identity and learning engagement were not high.

\subsection{Results of the Structural Model}

First, the relationship between professional identity and learning engagement were examined to check the predictive validity of the new scale. Specifically, the path coefficient ( $\beta=0.591, p<0.001)$ is obtained from the structural equation model of the direct effect of professional identity on learning engagement. Professional identity was shown in a positive correlation with learning engagement. Among the three dimensions of professional identity, professional emotion contributed the most $(\beta=0.829, p<0.001)$, followed by professional appraisal $(\beta=0.801, p<0.001)$, and professional cognition $(\beta=0.566, p<0.001)$.

Second, SEM was used to evaluate the relationships among professional cognition, professional appraisal, professional emotion and learning engagement. The fit indices indicated a satisfactory result: $\chi^{2} / \mathrm{df}=2.74, \mathrm{GFI}=0.88, \mathrm{CFI}=0.93, \mathrm{NFI}=0.90, \mathrm{IFI}=0.93$, RMSEA $=0.06$, and RMR $=0.05$. The structural paths and effects are presented in Figure 2, Table 4.

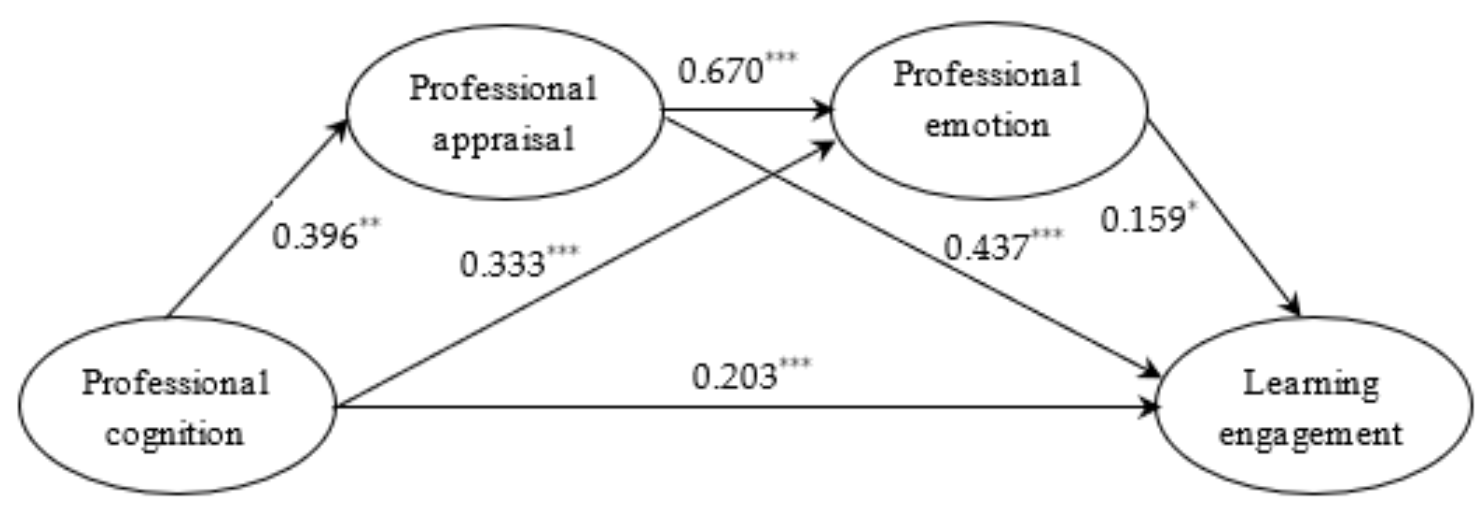

Figure 2. Results of hypothesis testing. Note: ${ }^{*} p<0.05,{ }^{* *} p<0.01,{ }^{* * *} p<0.001$.

Table 4. Direct effects, indirect effects and total effects of the latent variables in structural model.

\begin{tabular}{cccccc}
\hline $\begin{array}{c}\text { Influence } \\
\text { Paths }\end{array}$ & $\begin{array}{c}\text { Total } \\
\text { Effects }\end{array}$ & $\begin{array}{c}\text { Direct } \\
\text { Effects }\end{array}$ & $\begin{array}{c}\text { Indirect } \\
\text { Effects }\end{array}$ & $\begin{array}{c}\text { Standardized } \\
\text { Errors }\end{array}$ & t Value \\
\hline $\mathrm{PC} \rightarrow$ LE & 0.471 & 0.203 & 0.268 & 0.067 & 3.022 \\
$\mathrm{PC} \rightarrow$ PE & 0.599 & 0.333 & 0.265 & 0.054 & 6.142 \\
$\mathrm{PM} \rightarrow$ LE & 0.543 & 0.437 & 0.107 & 0.085 & 5.166 \\
$\mathrm{PC} \rightarrow$ PM & 0.396 & 0.396 & - & 0.054 & 7.348 \\
$\mathrm{PM} \rightarrow$ PE & 0.670 & 0.670 & - & 0.070 & 9.523 \\
$\mathrm{PE} \rightarrow \mathrm{LE}$ & 0.159 & 0.159 & - & 0.070 & 2.270 \\
\hline
\end{tabular}


As shown in Figure 2, all direct paths were statistically significant, supporting H1, $\mathrm{H} 2, \mathrm{H} 3, \mathrm{H} 5, \mathrm{H} 6$, and H7. In particular, the analysis results of the model demonstrated that professional cognition $(\beta=0.161, p<0.01)$, professional appraisal $(\beta=0.339, p<0.001)$, and professional emotion $(\beta=0.149, p<0.05)$ significantly influenced learning engagement. Professional cognition $(\beta=0.283, p<0.001)$, and professional appraisal $(\beta=0.555, p<0.001)$ significantly influenced professional emotion. The direct relationship between professional cognition and professional appraisal was also positive at $\beta=0.406, p<0.001$.

The bootstrap method was adopted to test the mediating role of professional emotion and professional appraisal [79]. The bootstrap method was widely used to check the indirect impact in the mediation model. The mediating effect of professional appraisal between professional cognition and professional emotion was shown significant $(\beta=0.265$, $p<0.001$ ), with the bias-corrected confidence intervals (B-CCI) ranging from 0.189 to 0.374, supporting H4. Similarly, the mediating effect of professional emotion between professional appraisal and learning engagement was shown not significant $(\beta=0.107$, $p=0.087$ ), with the B-CCI ranging from -0.013 to 0.247 ; H8 was rejected. In addition, according to the same testing method, the mediating effects of professional appraisal and professional emotion between professional cognition and learning engagement were also significant, thus, H9 and H10 were supported.

Table 4 shows that direct effects, indirect effects, and total effects of the latent variables in the structural model. According to the comparison of the magnitude and significance of the path coefficient, the direct effects were from strong to weak, shown as follows: $\mathrm{PM} \rightarrow \mathrm{PE}, \mathrm{PM} \rightarrow \mathrm{LE}, \mathrm{PC} \rightarrow \mathrm{PM}, \mathrm{PC} \rightarrow \mathrm{PE}, \mathrm{PC} \rightarrow \mathrm{LE}$, and $\mathrm{PE} \rightarrow$ LE. The total effects were from strong to weak, shown as follows: $\mathrm{PM} \rightarrow \mathrm{PE}, \mathrm{PC} \rightarrow \mathrm{PE}, \mathrm{PM} \rightarrow \mathrm{LE}, \mathrm{PC} \rightarrow \mathrm{LE}$, $\mathrm{PC} \rightarrow \mathrm{PM}, \mathrm{PE} \rightarrow$ LE. The results showed that university students have a clear cognition of tourism major, and the evaluation of the matching degree between the individual and the major will significantly affect students' positive or negative emotion of tourism major, or possibly negative emotion.

\section{Discussion and Conclusions}

The purpose of this study is threefold: to validate the professional identity model and measurement; to investigate Chinese undergraduate tourism students' professional identity; to examine the effects of the professional identity on learning engagement, and the relationships among professional cognition, professional appraisal, professional emotion, and learning engagement. Under the background of the COVID-19 pandemic and Chinese higher education reform, the importance of professional identity research is becoming more and more prominent [8]. The results of this study are useful for improving the competitiveness of undergraduate tourism students, and accelerating the sustainable development of tourism higher education. The findings reveal both theoretical and practical implications.

\subsection{Theoretical Implications}

First, the proposed model of professional identity is validated for the research context of Chinese undergraduate tourism students, which enriches the research field of professional identity. As mentioned in the literature review, the research focused on examining university tourism students' professional identity is very limited [7,28]-the prior research on professional identity mainly concentrated on educational and medical students $[40,80]$. This study further verified the impact of professional identity on learning engagement $[11,13]$. The employment prospect of university tourism students in China is not optimistic, and students' professional identity shows a downward trend. Both tourism higher education and tourism industry are severely challenged. In the past, the research did not attach enough importance to the effects of students' professional identity on learning engagement [7], but this research is helpful to understand the value of professional identity and its effects on learning engagement. In addition, this study also has an enlightening significance for other programs in universities. Second, this study establishes a 
measurement scale of professional identity, and evaluates undergraduate tourism students' professional identity in China. Most prior research has been qualitative, and quantitative tests of the related topic are scarce [81]. This research uses quantitative methods to measure and reveal that professional identity has a significant positive effect on learning engagement, which can significantly predict academic performance and employment competition. The previous research on the measurement of professional identity mainly focuses on developed countries [39,82]. However, this study takes China, a developing country, as an example. The current status of Chinese undergraduate tourism students' professional identity and learning engagement are not optimistic, which tends to weaken the employment competitiveness, and even affects the sustainable development of tourism education and the tourism industry [6,7]. The research noted that university students' professional identity could be improved to alleviate learning anxieties and enhance their satisfaction and engagement [13].

Third, this study reveals that the professional identity is a progressive, dynamic process from psychology to behavioral intention. Compared with previous studies $[7,22,28,45]$, it is noted that university students' professional identity consists of professional cognition, professional appraisal, and professional emotion based on the social identity theory and the professional identity research. There are few studies on the relationships between cognition, evaluation, emotion, and their positions in professional identity [31,43,44]. This study examines the impact of university tourism students' professional identity on learning engagement and tests the relationships among professional cognition, professional appraisal, professional emotion, and learning engagement. This study shows that professional cognition is positively related to professional appraisal, professional emotion, and learning engagement. Based on the above results, the professional appraisal significantly affects professional emotion and learning engagement. The professional emotion also significantly affects learning engagement. The professional identity has a superposition effect on learning engagement, and the promotion of professional identity is a multi-level progressive process and contributes to the professional identity education of tourism students. This is a meaningful and interesting conclusion, which is different from the previous research $[35,43]$.

Fourth, this study examines the mediating effects of professional appraisal and professional emotion between different variables to better understand the progressive, dynamic process of professional identity. Although earlier studies have concluded that there are important relationships between professional appraisal, professional emotion, and learning engagement $[83,84]$, scholars have rarely empirically tested the mediating role of professional appraisal and professional emotion. This study supports that professional appraisal plays a positive mediating role between professional cognition and professional emotion $[31,33]$. However, the mediating role of professional emotion between professional appraisal and learning engagement is not significant. According to the results of professional cognition, university students evaluate the matching degree between individual characteristics and professional development, so as to produce positive or negative professional emotions and strengthen or weaken learning enthusiasm. This is similar to other studies focusing on the classification of professional emotion and its impact on professional engagement $[43,51,52]$. Therefore, it is necessary to strengthen professional ideological education in order to enhance the matching degree between individual development and tourism major.

\subsection{Practical Implications}

First, this study offers insights into Chinese tourism higher education. Since the reform and opening-up policy, especially after 2000, the number of undergraduate tourism universities in China has increased significantly. However, the professional competitiveness and employment quality are not satisfactory due to internal and external adverse factors [4]. In particular, low professional identity is one of the influential factors, which has a negative impact on talent cultivation and professional development [6,7]. University students with 
a better understanding of tourism major hold that the development of the individual can better match with the major and produce positive learning emotion and learning behavior. We need to attach great importance to enhancing university tourism students' professional identity and promoting the high-quality development of tourism major. We need to carry out a comprehensive and in-depth survey of tourism's professional identity on a regular basis to understand what problems exist in tourism education [9]. At present, Chinese universities should start paying more attention to the professional ideological education of freshmen $[85,86]$.

Second, professional identity is a continuous progressive process, and its promotion is also a complicated systematic multi-level project, which needs to be continuously improved through a series of countermeasures. University can formulate a variety of professional education measures or activities in different forms and types such as classes, lectures, exchanges, discussions, investigations, etc., so that students can clearly understand both good prospects and existing problems of tourism major and tourism industry $[14,68,87,88]$.

University teachers need to pay attention to the ideological status and learning status of students and design effective intervention countermeasures. For example, a university could invite successful alumni to share their experience with students to offer them positive guidance and encouragement, and to improve university students' academic self-efficacy [89]. Students are encouraged to apply professional knowledge to solve the difficulties faced by the development of the tourism industry, and integrate the individual development to enhance the positive emotion of tourism major [9]. University students can be scientifically guided to understand the current situation of the tourism major, and adopt healthy and optimistic attitudes to face the difficulties encountered in learning [90].

Third, for different university student groups, sustained and accurate education policies for professional identity need to be formulated. Although university students personality characteristics are not easy to change, strategies still need to be customized based on the personalities of students. Professional identity varies due to different influencing factors such as individual characteristics. Therefore, differentiated education guiding policies are formulated according to students' identity in order to enhance the fit between individuals and the tourism major, and to improve the implementation effects of identity policies [11]. In addition, according to the characteristics of senior students, the corresponding professional identity education policies are carried out to develop students' attachment to the tourism major [89].

Fourth, the issue of tourism students' professional identity varies in different regions and countries. Chinese university tourism students' professional identity is greatly influenced by traditional culture and social concepts. Compared with developed countries [39,82], the relatively low level of technology, wages, and social status have led to a high rate of transferring majors and a weak professional identity [28,91]. The COVID-19 pandemic has exacerbated the negative impacts of the problem [12]. Government, society, enterprises, and universities need to work together to weaken the negative impacts of social and cultural background through active intervention and re-building students' professional confidence on the tourism profession [13]. For example, according to the requirements of talent training, students are advised to formulate a phased learning plan and reasonable career planning to increase learning engagement through strengthening university-enterprise cooperation. Both society and university create a good learning environment inside and outside the campus, providing economic, psychological support for the tourism major, and establishing a creative atmosphere in tourism education [2]. It shortens the psychological distance between teachers and students, and enhances their sense of belonging to the major. In addition, joint efforts could be made to improve the entry salary level of tourism graduates and to create a more positive professional identity. Only through everyone's joint efforts, the professional identity of tourism university students could be improved. 


\section{Limitations and Future Research}

This study has two limitations that need to be surmounted in future research. First, the sample was drawn from 10 universities in Jiangsu province, China. Jiangsu is a province with a higher level of development in the tourism industry and higher education in China. However, the unbalanced development of China's tourism industry and tourism higher education is very prominent. As a result, the conclusions and enlightenment of this research may be more applicable to China's developed provinces. Therefore, future studies can extend the research contexts to different areas in China. Second, this study focuses on the impact of undergraduate tourism students' professional identity on learning engagement. However, there is a lack of discussion on the factors affecting students' professional identity and learning engagement. Future studies could consider investigating the influencing factors and carry out more comprehensive and in-depth research examining the relationship between different factors, professional identity, and learning engagement.

Author Contributions: Conceptualization, F.Y.; methodology, F.Y. and Q.C.; software, F.Y. and B.H.; validation, F.Y., Q.C. and B.H.; formal analysis, F.Y.; investigation, F.Y.; resources, Q.C.; data curation, B.H.; writing—original draft preparation, F.Y.; writing—review and editing, Q.C.; funding acquisition, B.H. All authors have read and agreed to the published version of the manuscript.

Funding: This research was funded by the National Natural Science Foundation of China Grant number (41771146).

Institutional Review Board Statement: The study was conducted according to the guidelines of the Declaration of Helsinki, and approved by the Ethics Committee of Yangzhou University (protocol code LP2021050518 and 5 May 2021).

Informed Consent Statement: Informed consent was obtained from all subjects involved in the study.

Conflicts of Interest: The authors declare no conflict of interest.

\section{References}

1. Tsai, C.T.; Hsu, H.; Hsu, Y.C. Tourism and hospitality college students' career anxiety: Scale development and validation. J. Hosp. Tour. Educ. 2017, 29, 158-165. [CrossRef]

2. Li, Y.Q.; Liu, C.H. How to establish a creative atmosphere in tourism and hospitality education in the context of China. J. Hosp. Leis. Sport Tour. Educ. 2016, 18, 9-20. [CrossRef]

3. Qu, H.; Leung, X.Y.; Huang, S.S.; He, J.M. Factors affecting hotel interns' satisfaction with internship experience and career intention in China. J. Hosp. Leis. Sport Tour. Educ. 2021, 28, 100311. [CrossRef]

4. Bao, J.G.; Zhu, F. On the shrinking of China's tourism undergraduate education and way out: Thoughts about thirty years of development of tourism higher education. Tour. Trib. 2008, 23, 13-17.

5. Chen, J.H.; Shi, H.; Dong, Y.; Yang, M.; Han, Z. Can engagement in learning enhance tourism undergraduates' employability? A case study. Int. J. Electr. Eng. Educ. 2020. [CrossRef]

6. Bai, K.; Ni, R.; Bai, D. Discipline identity in the major of tourism management: Scale development and dimensional measurement. Tour. Trib. 2012, 27, 42-48.

7. Wang, J. Professional identity of tourism management program: A perspective from undergraduate students in China. Tour. Hosp. Prospect. 2018, 2, 56-74.

8. Carmen, M.; Carlos, M.; Yubero, C. Higher education and the sustainable tourism pedagogy: Are tourism students ready to lead change in the post pandemic era? J. Hosp. Leis. Sport Tour. Educ. 2021, 28, 100311.

9. Ramakrishnan, S.; Macaveiu, C. Understanding aspirations in tourism students. J. Hosp. Tour. Manag. 2019, 39, 40-48. [CrossRef]

10. UNWTO. COVID-19 and Tourism 2020: A Year in Review; UNWTO: Madrid, Spain, 2021; pp. 2-10.

11. Ina Reichenberger, I.; Marguerite, R. Tourism students' career strategies in times of disruption. J. Hosp. Tour. Manag. 2021, 48, 220-229. [CrossRef]

12. Joshi, V.A.; Gupta, I. Assessing the impact of the COVID-19 pandemic on hospitality and tourism education in India and preparing for the new normal. Worldw. Hosp. Tour. Themes 2021, 13, 622-635. [CrossRef]

13. Siow, M.L.; Lockstone-Binney, L.; Fraser, B.; Cheung, C.; Shin, J.; Lam, R.; Ramachandran, S.; Novais, M.A.; Bourkel, T.; Baum, T. Re-building students' post-covid-19 confidence in courses, curriculum and careers for tourism, hospitality, and events. J. Hosp. Tour. Educ. 2021, 33, 270-287. [CrossRef]

14. Qiu, H.; Li, Q.; Li, C. How technology facilitates tourism education in covid-19: Case study of Nankai university. J. Hosp. Leis. Sport Tour. 2020, 29, 100288. [CrossRef] 
15. Zhang, B. Analysis on employment demand of graduates majoring in tourism management in colleges and universities in Hebei province under the background of epidemic situation. Employ. Secur. 2021, 3, 187-188.

16. CPC Central Committee; State Council. Overall Plan for Deepening the Reform of Educational Evaluation in the New Era. 13 October 2020. Available online: http:/ / www.gov.cn/zhengce/2020-10/13/content_5551032.htm (accessed on 1 October 2021).

17. Richardson, S. Generation Y's perceptions and attitudes towards a career in tourism and hospitality. J. Hum. Resour. Hosp. Tour. 2010, 9, 179-199. [CrossRef]

18. Guo, J.; Yang, L.; Shi, Q. Effects of perceptions of the learning environment and approaches to learning on Chinese undergraduates' learning. Stud. Educ. Eval. 2017, 55, 125-134. [CrossRef]

19. Fredricks, J.A.; Filsecker, M.; Lawson, M.A. Student engagement, context, and adjustment: Addressing definitional, measurement, and methodological issues. Learn. Instr. 2016, 43, 1-4. [CrossRef]

20. Zepke, N. Student engagement research in higher education: Questioning an academic orthodoxy. Teach. High. Educ. 2014, 19, 697-708. [CrossRef]

21. Buzinde, C.N.; Vogt, C.A.; Andereck, K.L.; Pham, L.H.; Ngo, L.T.; Do, H.H. Tourism students' motivational orientations: The case of Vietnam. Asia Pac. J. Tour. Res. 2018, 23, 68-78. [CrossRef]

22. Schaufeli, W.B.; Salanova, M.; Gonzalez-roma, V.; Bakker, A.B. The measurement of engagement and burnout: A two sample confirmatory factor analytic approach. J. Happiness Stud. 2002, 3, 71-92. [CrossRef]

23. Cooper, J.; Giousmpasoglou, C.; Marinakou, E. Occupational identity and culture: The case of michelin-starred chefs. Int. J. Contemp. Hosp. Manag. 2017, 29, 1362-1379. [CrossRef]

24. Tang, Y.P. It's not only work and pay: The moderation role of teachers' professional identity on their job satisfaction in rural China. Appl. Res. Qual. Life 2019, 15, 971-990. [CrossRef]

25. Mancini, T.; Caricati, L.; Panari, C.; Tonarelli, A. Personal and social aspects of professional identity. An extension of Marcia's identity status model applied to a sample of university students. J. Vocat. Behav. 2015, 89, 140-150. [CrossRef]

26. Zhang, M.; Li, R. The Effect of speciality identity on university students' learning engagement: The mediating role of school belonging. Heilongjiang Res. High. Educ. 2018, 3, 94-99.

27. Li, Y.; Meng, L.; Wang, M.; Feng, X. The effect of professional identity on learning engagement: A multiple mediation model. Psychol. Technol. Appl. 2017, 5, 536-541.

28. Wang, C.H.; Xu, J.H.; Zhang, T.C.; Li, Q. Effects of professional identity on turnover intention in China's hotel employees: The mediating role of employee engagement and job satisfaction. J. Hosp. Tour. Manag. 2020, 45, 10-22. [CrossRef]

29. Turner, H. Social Identity and Inter-Group Relations; Cambridge University Press: Cambridge, UK, 1982.

30. Ashforth, B.; Mael, F. Social identity theory and the organization. Acad. Manag. Rev. 2012, 2, 4-27.

31. Gomez, A.; Vazquez, A. Personal identity and social identity: Two different processes or a single one? Int. J. Soc. Psychol. 2015, 30, 468-480. [CrossRef]

32. Hogg, M.A. Subjective uncertainty reduction through self-categorization: A motivational theory of social identity processes. Eur. Rev. Soc. Psychol. 2000, 11, 223-255. [CrossRef]

33. Jenkins, R. Social Identity; Routledge: New York, NY, USA, 2014.

34. Smilde, R. Biography, identity, improvisation, sound: Intersections of personal and social identity through improvisation. Arts Humanit. High. Educ. 2016, 15, 308-324. [CrossRef]

35. Dick, R.V.; Wagner, U.; Stellmacher, J.; Christ, O. The utility of a broader conceptualization of organizational identification: Which aspects really matter? J. Occup. Organ. Psychol. 2004, 77, 171-191. [CrossRef]

36. Trede, F.; Macklin, R.; Bridges, D. Professional identity development: A review of the higher education literature. Stud. High. Educ. 2012, 37, 365-384. [CrossRef]

37. Tan, C.P.; Van der Molen, H.T.; Schmidt, H.G. A measure of professional identity development for professional education. Stud. High. Educ. 2017, 42, 1504-1519. [CrossRef]

38. Martin, F.; Doris, U.B. Engagement matters: Student perceptions on the importance of engagement strategies in the online learning environment. Online Learn. 2018, 22, 205-222. [CrossRef]

39. Burnard, P.; Dragovic, T.; Ottewell, K.; Lim, W.M. Voicing the professional doctorate and the researching professional's identity: Theorizing the edd's uniqueness. Lond. Rev. Educ. 2018, 16, 40-55. [CrossRef]

40. Gross, M.; Hochberg, N. Characteristics of place identity as part of professional identity development among pre-service teachers. Cult. Stud. Sci. Educ. 2016, 11, 1243-1268. [CrossRef]

41. Tian, M.; Lu, G.S.; Yin, H.B.; Li, L.J. Student engagement for sustainability of Chinese international education: The case of international undergraduate students in China. Sustainability 2020, 12, 6831. [CrossRef]

42. Pekrun, R. The control-value theory of achievement emotions: Assumptions, corollaries, and implications for educational research and practice. Educ. Psychol. Rev. 2006, 18, 315-341. [CrossRef]

43. Dodd, A.L.; Mansell, W.; Morrison, A.P.; Tai, S. Factor structure of the hypomanic attitudes and positive predictions inventory in a student sample. Personal. Individ. Differ. 2011, 50, 349-354. [CrossRef]

44. Li, N.; Chen, G.; Zhao, X.; Hong, M.; Zhang, X. Construction of cognitive model and empirical analysis of influencing factors of tourism management undergraduate major in local universities. J. Hunan Univ. Sci. Eng. 2021, 42, 60-64.

45. Yu, F.L. On the professional identity of undergraduates majoring in tourism management. J. Yangzhou Coll. Educ. 2020, 38, 70-74. 
46. Chen, S. The investigation and analysis of tourism management students' cognition, emotion and employment intention of professional: Taking Nanyang normal university as an example. J. Nanyang Norm. Univ. 2013, 12, 74-78.

47. Gao, X.; Yan, Y. Research on professional cognition, employment intention and professional loyalty of tourism management undergraduates. J. Ningxia Univ. 2012, 34, 175-179.

48. Warr, P.; Inceoglu, I. Job engagement, job satisfaction, and contrasting associations with person-job fit. J. Occup. Health Psychol. 2012, 17, 129-138. [CrossRef] [PubMed]

49. De Simone, S.; Planta, A.; Cicotto, G. The role of job satisfaction, work engagement, self-efficacy and agentic capacities on nurses' turnover intention and patient satisfaction. Appl. Nurs. Res. 2017, 39, 130-140. [CrossRef]

50. Shao, K.Q.; Pekrun, R.; Marsh, H.W.; Loderer, K. Control-value appraisals, achievement emotions, and foreign language performance: A latent interaction analysis. Learn. Instr. 2020, 69, 101356. [CrossRef]

51. Roseman, I.J. Cognitive determinants of emotion: A structural theory. Personal. Soc. Psychol. 1984, 5, 11-36.

52. Roseman, I.J.; Spindel, M.S.; Jose, P.E. Appraisals of emotion-eliciting events: Testing a theory of discrete emotions. J. Personal. Soc. Psychol. 1990, 59, 899-915. [CrossRef]

53. Parker, P.C.; Perry, R.P.; Hamm, J.M.; Chipperfield, J.G.; Tze, V. A motivation perspective on achievement appraisals, emotions, and performance in an online learning environment. Int. J. Educ. Res. 2021, 108, 101772. [CrossRef]

54. Kahu, E.R. Framing student engagement in higher education. Stud. High. Educ. 2013, 38, 758-773. [CrossRef]

55. Ben-Eliyahu, A.; Moore, D.; Dorph, R.; Schunn, C.D. Investigating the multidimensionality of engagement: Affective, behavioral, and cognitive engagement across science activities and contexts. Contemp. Educ. Psychol. 2018, 53, 87-105. [CrossRef]

56. Zhoc, K.C.; Webster, B.J.; King, R.B.; Li, J.C.; Chung, T.S. Higher education student engagement scale (HESES): Development and psychometric evidence. Res. High. Educ. 2019, 60, 219-244. [CrossRef]

57. Lei, H.; Cui, Y.H.; Zhou, W.Y. Relationships between student engagement and academic achievement: A meta-analysis. Soc. Behav. Personal. 2018, 46, 517-528. [CrossRef]

58. Kim, S.; Kim, D.J. Structural relationship of key factors for student satisfaction and achievement in asynchronous online learning. Sustainability 2021, 13, 6734. [CrossRef]

59. Jepson, A.; Ryan, W.G. Applying the motivation, opportunity, ability (MOA) model, and self-efficacy (S-E) to better understand student engagement on undergraduate event management programs. Event Manag. 2018, 22, 271-285. [CrossRef]

60. Asikainen, H.; Gijbels, D. Do students develop towards more deep approaches to learning during studies? A systematic review on the development of students' deep and surface approaches to learning in higher education. Educ. Psychol. Rev. 2017, 29, 205-234. [CrossRef]

61. Skinner, E.; Marchand, G.; Furrer, C.; Kindermann, T. Engagement and disaffection in the classroom: Part of a larger motivational dynamic? J. Educ. Psychol. 2008, 100, 765-781. [CrossRef]

62. Laird, T.F.; Seifert, T.A.; Pascarella, E.T.; Mayhew, M.J.; Blaich, C.F. Deeply affecting first-year students' thinking: Deep approaches to learning and three dimensions of cognitive development. J. High. Educ. 2014, 85, 402-432. [CrossRef]

63. Hong, W.; Zhen, R.; Liu, R.D.; Wang, M.T.; Ding, Y.; Wang, J. The longitudinal linkages among Chinese children's behavioural, cognitive, and emotional engagement within a mathematics context. Educ. Psychol. 2020, 40, 666-680. [CrossRef]

64. Green, J.; Liem, G.; Martin, A.J.; Colmar, S.; Marsh, H.W.; Mcinerney, D. Academic motivation, self-concept, engagement, and performance in high school: Key processes from a longitudinal perspective. J. Adolesc. 2012, 35, 1111-1122. [CrossRef] [PubMed]

65. Vermunt, J.D.; Vermetten, Y.J. Patterns in student learning: Relationships between learning strategies, conceptions of learning, and learning orientations. Educ. Psychol. Rev. 2004, 16, 359-384. [CrossRef]

66. Biggs, J.; Kember, D.; Leung, D.Y. The revised two-factor study process questionnaire: R-SPQ-2F. Br. J. Educ. Psychol. 2001, 71, 133-149. [CrossRef]

67. Song, J.; Qu, H.L. The mediating role of consumption emotions. Int. J. Hosp. Manag. 2017, 66, 66-76. [CrossRef]

68. Gao, B.W.; Jing, J.; Tang, Y. The effect of blended learning platform and engagement on students' satisfaction: The case from the tourism management teaching. J. Hosp. Leis. Sport Tour. Educ. 2020, 27, 100272. [CrossRef]

69. Stefanini, C.J.; Rejowski, M.; Ferro, R.C. Tourism and hospitality in Brazil: A model for studies of education competencies. J. Hosp. Leis. Sport Tour. Educ. 2020, 29, 100299. [CrossRef]

70. Qin, P. The Characteristics and Correlation Study of College Students Specialty Identity. Master's Thesis, Southwest University, Chongqing, China, May 2009.

71. Li, X.; Huang, A. Revise of the UWES-S of Chinese college samples. Psychol. Res. 2010, 3, 84-88.

72. Lin, J.; Liu, Y.; Peng, W. Emotion and learning engagement: The mediating role of academic self-efficacy. Chin. J. Spec. Educ. 2020, 4, 89-96.

73. Wen, H.; Leung, X.; Li, X.; Kwon, J. What influences Chinese students' intentions to pursue hospitality careers? A comparison of three-year versus four-year hospitality programs. J. Hosp. Leis. Sports Tour. Educ. 2018, 23, 70-81. [CrossRef]

74. Tabachnick, B.G.; Fidell, L.S. Using Multivariate Statistics, 2nd ed.; Pearson Education: Boston, MA, USA, 2013.

75. Velicer, W.F.; Fava, J.L. Affects of variable and subject sampling on factor pattern recovery. Psychol. Methods 1998, 3, $231-251$. [CrossRef]

76. Hair, J.F.; Black, W.C.; Babin, B.J.; Anderson, R.E. Multivariate Data Analysis; Prentice Hall: Englewood Cliffs, NJ, USA, 2010; pp. 629-686. 
77. Hu, L.T.; Bentler, P.M. Cutoff criteria for fit indexes in covariance structure analysis: Conventional criteria versus new alternatives. Struct. Equ. Model. A Multidiscip. J. 1999, 6, 1-55. [CrossRef]

78. Fornell, C.; Larcker, D.F. Evaluating structural equation models with unobservable variables and measurement error. J. Mark. Res. 1981, 18, 39-50. [CrossRef]

79. Fritz, M.S.; Taylor, A.B.; MacKinnon, D.P. Explanation of two anomalous results in statistical mediation analysis. Multivar. Behav. Res. 2012, 47, 61-87. [CrossRef]

80. Goldie, J. The formation of professional identity in medical students: Considerations for educators. Med Teach. 2012, 34, 641-648. [CrossRef] [PubMed]

81. Brien, A.; Thomas, N.J.; Brown, E.A. How hotel employee job-identity impacts the hotel industry: The uncomfortable truth J. Hosp. Tour. Manag. 2017, 31, 235-243. [CrossRef]

82. Tinkler, L.; Smith, V.; Yiannakou, Y.; Robinson, L. Professional identity and the clinical research nurse: A qualitative study exploring issues having an impact on participant recruitment in research. J. Adv. Nurs. 2017, 74, 318-328. [CrossRef]

83. Sabanciogullari, S.; Dogan, S. Relationship between job satisfaction, professional identity and intention to leave the profession among nurses in Turkey. J. Nurs. Manag. 2015, 23, 1076-1085. [CrossRef] [PubMed]

84. Provan David, J.; Dekker Sidney, W.A.; Rae Andrew, J. Benefactor or burden: Exploring the professional identity of safety professionals. J. Saf. Res. 2018, 66, 21-32. [CrossRef]

85. Yang, M. Discussion on the reform of the talent training mode for tourism management major under the guidance of undergraduate qualified evaluation index: Taking Taizhou university as an example. J. Beijing City Univ. 2020, 3, 83-88.

86. Liu, Y. Curriculum reform and practice analysis of the teaching and education of tourism management majors in colleges and universities. Educ. Teach. Forum 2021, 41, 105-108.

87. Tavitiyaman, P.; Ren, L.; Fung, C. Hospitality students at the online classes during covid-19: How personality affects experience? J. Hosp. Leis. Sport Tour. 2021, 28, 100304. [CrossRef]

88. Kim, K.J.; Davies, J. A teacher's perspective on student centred learning: Towards the development of best practice in an undergraduate tourism course. J. Hosp. Leis. Sport Tour. Educ. 2014, 14, 6-14. [CrossRef]

89. Chau, S.; Cheung, C. Academic satisfaction with hospitality and tourism education in Macao: The influence of active learning, academic motivation, and student engagement. Asia Pac. J. Educ. 2018, 38, 473-487. [CrossRef]

90. Matteucci, X.; Aubke, F. Experience care: Efficacy of service-learning in fostering perspective transformation in tourism education. J. Teach. Travel Tour. 2018, 18, 8-24. [CrossRef]

91. Brown, E.A.; Thomas, N.J.; Bosselman, R. Are they leaving or staying: A qualitative analysis of turnover issues for generation $Y$ hospitality employees with a hospitality education. Int. J. Hosp. Manag. 2015, 46, 130-137. [CrossRef] 